\title{
Vitamin $D$ receptor polimorphism can be associated with coronary artery disaese
}

\author{
Sadık Volkan Emren*, Mehmet Tokaç \\ Katip Celebi University School of Medicine Department of Cardiology, Izmir, Turkey
}

Key Words: Vitamin D, coronary heart disaese, gene polimorphism

To the Editor,

We have read the article entitled " Assessment of vitamin $\mathrm{D}$ levels in patients with acute coronary syndrome" by Simsek and Babat. (1) with great pleasure, which was published in East $\mathrm{J}$ Med 2016; 21(4):178-182. We congratulated the authors for this excellent study. In this study the investigators reported that Vitamin D insufficiency is not a risk factor for acute coronary syndrome. According to the results of this study, there was no association between vitamin D plasma level and the risk of acute coronary syndrome. In this regard we aim to highlight some points regarding the relation between vitamin $\mathrm{D}$ and coronary artery disease.

Vitamin D receptor gene polymorphism can also be associated with coronary artery disease regardless of vitamin D level. Abu El Maaty et al. (2) has recently reported that Vitamin D receptor polymorphism especially Fok1 gene has been related to coronary artery disease, although the determined vitamin $\mathrm{D}$ genotypes were not related to vitamin D levels. Besides Hossein- Nezhad et al. (3) demonstrated the association of Fok1 polymorphism with the level of collateralization in patients with coronary artery disease however we have no data about the association with vitamin $\mathrm{D}$ polymorphism and coronary artery disease in Turkish population. In this context we advise to investigate the vitamin $\mathrm{D}$ receptor gene polymorphism in order to delineate the association with coronary artery disease and vitamin D.

\section{References}

1. Simsek H, Babat N. Assesment of vitamin D levels in patients with acute coronary syndrome East J Med 2016; 21: 178-182.

2. Abu El Maaty MA, Hassanein SI, Gad MZ. Genetic variation in vitamin D receptor gene (Fok1:rs2228570) is associated with risk of coronary artery diseae. Biomarkers 2016; 21: 6872.

3. Hossein-Nezhad A, Eshaghi SM, Maghbooli Z, et al. The role of vitamin $\mathrm{D}$ deficiency and vitamin d receptor genotypes on the degree of collateralization in patients with suspected coronary artery disease. Biomed Res Int. 2014; 30: $42-50$. 